International Journal of Current Microbiology and Applied Sciences

ISSN: 2319-7706 Volume 6 Number 3 (2017) pp. 1085-1091

Journal homepage: http://www.ijcmas.com

Original Research Article

https://doi.org/10.20546/ijcmas.2017.603.125

\title{
Effect of NPK on Plant Growth, Yield and Quality of Capsicum (Capsicum annum L.) c.v. Swarna Under Shade Net Condition
}

\section{Ashish Kumar Dubey ${ }^{1}$, Devi Singh ${ }^{1}$, Pranjal Singh Rajput ${ }^{1}$, Yogesh Kumar ${ }^{2}$, Ajay Kumar Verma ${ }^{3}$ and Sandip Kumar Chandraker ${ }^{4} *$}

${ }^{1}$ Department of Horticulture, Sam Higginbottom Institute of Agriculture,

Technology and Science, Allahabad-211007 (U.P.), India

${ }^{2}$ Department of Environmental Science, Indira Gandhi National Tribal University,

Amarkantak-484887(MP), India

${ }^{3}$ ICAR-Central Institute for Arid Horticulture, Bikaner-334006 (Rajasthan), India

${ }^{4}$ Department of Botany, Indira Gandhi National Tribal University,

Amarkantak-484887(MP), India

*Corresponding author

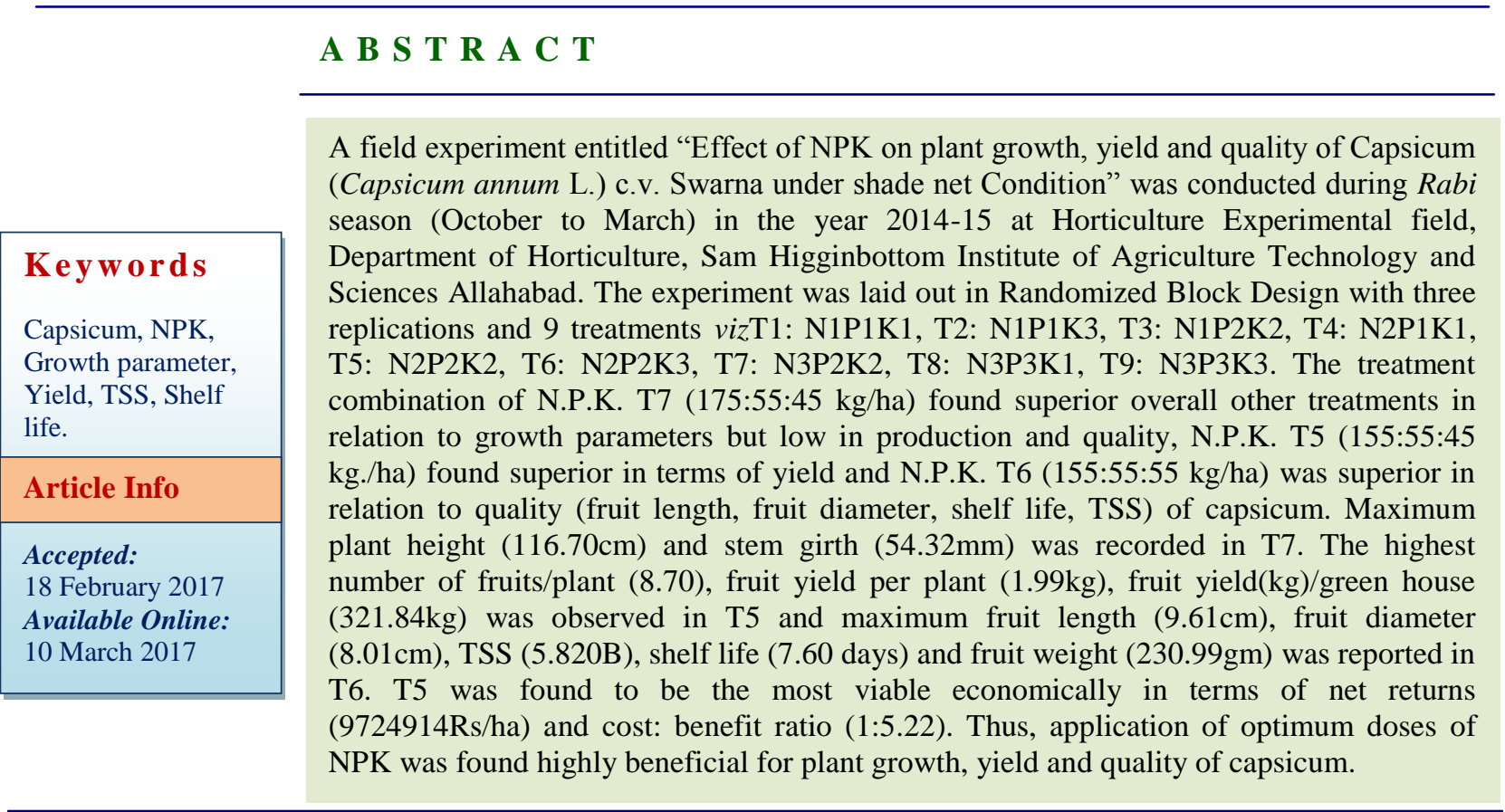

\section{Introduction}

Chili (C.annuum L.) is an important crop belongs to the family Solanaceae. Cultivated chilies are of American origin and have been discovered in the pre-historic remains of Peru. Chili is the third important crop of family Solanaceae after tomato and potato (Naz, 2006).
The total area under chilies cultivation in India was 30,000 hectares with total production of $1,72,000$ tones in which the maximum area comes under Jharkhand, whereas the highest production is shared by Karnataka (Horticulture Statistics, 2015). 
Chilies grow best on a well-drained, silt or clay loam soil. The production and yield of plant depend on sufficient availability of required nutrients. The mineral nutrients, N, P and $\mathrm{K}$ are known to affect growth and yield of the capsicums. Applications of $\mathrm{N}$ fertilizer levels showed significant effect on all growth and yield parameters. Yield in pepper increased with increase in nitrogen $(\mathrm{N})$ level but excessive $\mathrm{N}$ application may also decrease the yield (Khan et al., 2014). The Nitrogen application increases the productivity but the geography including soil, climate plays an important role in the response of nitrogen fertilizer for overall effect on the productivity (Lebauer and Treseder, 2008). It was reportedthat $\mathrm{N}$ fertilizer increased fruit weight, yield and fruit number of chili peppers (Tumbare and Niikam, 2004). Improved nitrogen management can be achieved by matching nitrogen supply with crop need and selecting appropriate nitrogen level to minimize nitrate nitrogen accumulation in soil at times, when the leaching potential is high (Papendick, 1987). In severe cases of excess nitrogen, leaves developed necrotic lesions followed by defoliation.

It is evident from literature, that potash affects mostly the quality of fruits and vegetables. Potassium is one of the three major nutrients (N, P and K) needed for plant growth (Russo, 1991 and Hartz, 1993). Potassium plays a main role in plant metabolism such as photosynthesis, translocation of photosynthesis, water relation as well as enzyme activation. Although, potassium is not a constituent of any plant structures or compounds, but it plays a part in many important regulatory roles in the plant, i.e. osmo-regulation process, regulation of plant stomata and water use, translocation of sugars and formation of carbohydrates, energy status of the plant, the regulation of enzyme activities, protein synthesis and many other processes needed to sustain plant growth and reproduction (Hsiao and Lauchli, 1986). It is a highly mobile element in the plant and has a specific phenomenon, it is called luxury consumption. In addition, it plays a very important role in plant tolerance of biotic and a-biotic stresses (Marschner, 1995). Potassium is also known as the quality nutrient because of its important effects on quality factors (Lester, 2006). With the exception of nitrogen, potassium is required by plants in much greater amounts than all the other soil-supplied nutrients (Tisdale, 1985). Therefore, this experiment was designed to find a proper level of nitrogen and potassium for growth and yield of chili (C. annuum L.) under the agro-climatic conditions of Dargai, Malakand.

\section{Materials and Methods}

The experiment entitled "Effect of NPK on plant growth, yield and quality of Capsicum (C. annum L.) c.v.- Swarna under shade net Condition.' was carried out at the research plot of the Department of Horticulture, Sam Higginbottom Institute of Agriculture, Technology and Sciences Allahabad, of Rabi season during 2014-15 session under Allahabad Agro-climatic conditions. The experimental site is situated N-20 $10^{\circ}$ and E$60^{\circ} 3^{\prime}$ ' and at an altitude of 98 meters above mean sea level (MSL). In order to study the physical and chemical properties of soil, a composite soil sample was taken from 0-30 $\mathrm{cm}$ depth by adopting appropriate soil sampling techniques before sowing. The soil selected for the experiment was medium black with good texture and drainage. The land was prepared thoroughly by ploughing the land 3-4 time to obtain a fine tilt followed by planking to level the field. Before conducting any experiment, it is essential to ascertain the physical and chemical condition of the soil and its nutrient status, so the physico-chemical analysis of soil was performed before the commencement of the 
experiment. Based on the above analysis the soil of the experimental field was sandy loam in texture, poor in nitrogen, comparatively rich in phosphorus and medium in potash with slightly alkaline reaction.

The experiment was laid out in Factorial Randomized Block Design comprising of 9 treatments each replicated 3 times. Treatments were randomly arranged in each replication, divided into nine plots. Seeds of capsicum were sown separately in the nursery (C.P.C.T., I.A.R.I. New Delhi) on $29^{\text {th }}$ September 2014. The thirty day old seedlings were collected from I.A.R.I. New Delhi and transplanted on $31^{\text {st }}$ October 2014, in prepare field. The first observation was taken at 30 days after transplanting (DAT) that was $31^{\text {st }}$ November 2014. Subsequent observations were recorded after every 30 days interval. Thirty days old healthy seedlings having 4-5 leaves with a height of $15-18 \mathrm{~cm}$ were selected and transplanted at the experimental plot and given light irrigation.

The farm yard manure @ 20-25 tones ha-1 Nitrogen was applied in the form of Urea, Phosphorus as SSP and Potassium as MOP before transplanting of seedlings respectively at the time of transplanting. In each plot fertilizers were applied as per treatment combination mentioned above and mixed thoroughly in the soil with the help of khurpi. The technique of representative sample was adopted for recording the observations on various morphological characters in Capsicum. At every observation, five plants from each plot were randomly selected and tagged. The observations were recorded from these plants. The observations were tabulated and analyzed. The data were processed and subjected to analysis of variance. The ' $F$ ' test as suggested by Prof. Snendicor and Yates was used to determine significant difference between the treatments.

\section{Results and Discussion}

The maximum plant height at 30, 60, 90, 120 and 150 days after planting was recorded in T7: NPK@ 175:55:45 kg/ha with $(35.76 \mathrm{~cm}$, $50.10 \mathrm{~cm}, 66.73 \mathrm{~cm}, 89.10 \mathrm{~cm}$ and $116.70 \mathrm{~cm}$ respectively) followed by T9: NPK@ $175: 70: 55 \mathrm{~kg} / \mathrm{ha}$ with $(31.03 \mathrm{~cm}, 45.37 \mathrm{~cm}$, $61.97 \mathrm{~cm}, \quad 84.37 \mathrm{~cm}$ and $111.97 \mathrm{~cm}$ respectively) and the minimum was recorded in T1 (control) NPK@ 135:40:35 kg/ha with $(18.46 \mathrm{~cm}, 32.87 \mathrm{~cm}, 49.47 \mathrm{~cm}, 71.77 \mathrm{~cm}$ and $99.30 \mathrm{~cm}$ respectively). It was noticed that plant height increased successively with the increasing levels of NPK. Combination of highest levels of NPK also recorded maximum plant height (Table 1). The higher plant height might be due to abundant supply of nitrogen and phosphorus which helped the plants in better photosynthesis to attain vigor. These findings are in conformity with the results reported by Balliu et al., (2007); Abdelaziz et al., (2008) and Yasuor (2013). The maximum stem girth $(\mathrm{mm})$ at $30,60,90$, 120 and 150 days after planting was record in T7: NPK@ 175:55:45 kg/ha with $(13.37 \mathrm{~mm}$, $23.49 \mathrm{~mm}, 35.70 \mathrm{~mm}, 47.07 \mathrm{~mm}$ and 54.32 $\mathrm{mm}$ ), followed by T9: NPK@ 175:70:55 $\mathrm{kg} /$ ha with $(13.01 \mathrm{~mm}, 23.13 \mathrm{~mm}, 35.31 \mathrm{~mm}$, $46.71 \mathrm{~mm}$ and $54.21 \mathrm{~mm}$ ), whereas the minimum was recorded in $\mathrm{T} 1$ (control) NPK@ 135:40:35 kg/ha with (11.66 mm, $21.78 \mathrm{~mm}, 33.96 \mathrm{~mm}, 45.34 \mathrm{~mm}$ and 52.94 $\mathrm{mm})$. The maximum number of fruits/plant was recorded in T5: $155: 55: 45 \mathrm{~kg} / \mathrm{ha}$ with (8.70), followed by T9: $175: 70: 55 \mathrm{~kg} /$ ha with (8.20) and the minimum was recorded in T1: (control) with (135:40:35 kg/ha with (4.90). This was probably due to better vegetative growth of plants with availability of sufficient nitrogen, phosphorus, potassium and other essential nutrients which were further supplemented by soil at different stages of nutrient requirement by the plants. 
Int.J.Curr.Microbiol.App.Sci (2017) 6(3): 1085-1091

Table.1 Growth parameters of capsicum influenced by different doses of NPK in shade net condition

\begin{tabular}{|c|c|c|c|c|c|c|c|c|c|c|c|}
\hline \multirow[t]{2}{*}{ Treatment } & \multirow{2}{*}{$\begin{array}{c}\text { Treatment } \\
\text { combination }\end{array}$} & & \multicolumn{4}{|c|}{ Effect of NPK on plant height $(\mathrm{cm})$} & \multirow[b]{2}{*}{ 30 DAT } & \multicolumn{4}{|c|}{ Effect of NPK on stem girth (mm) } \\
\hline & & 30 DAT & 60 DAT & 90 DAT & 120 DAT & 150 DAT & & 60 DAT & 90 DAT & $\begin{array}{c}120 \\
\text { DAT }\end{array}$ & $\begin{array}{c}\text { 150 } \\
\text { DAT }\end{array}$ \\
\hline $\mathrm{T}_{1}$ & 135:40:35kg/ha NPK & 18.46 & 32.87 & 49.47 & 71.77 & 99.30 & 11.66 & 21.78 & 33.96 & 45.34 & 52.94 \\
\hline $\mathrm{T}_{2}$ & $135: 40: 55 \mathrm{~kg} / \mathrm{ha}$ NPK & 21.2 & 35.50 & 52.10 & 74.83 & 102.43 & 11.74 & 21.86 & 34.04 & 45.47 & 53.04 \\
\hline $\mathrm{T}_{3}$ & $135: 55: 45 \mathrm{~kg} / \mathrm{ha}$ NPK & 22.36 & 36.77 & 53.37 & 75.77 & 103.37 & 11.99 & 22.11 & 34.29 & 45.69 & 53.29 \\
\hline $\mathrm{T}_{4}$ & $155: 40: 35 \mathrm{~kg} / \mathrm{ha}$ NPK & 23.6 & 37.97 & 54.57 & 76.97 & 104.57 & 12.14 & 22.26 & 34.44 & 45.84 & 53.37 \\
\hline $\mathrm{T}_{5}$ & 155:55:45 kg/ha NPK & 232.5 & 46.90 & 63.50 & 85.90 & 113.50 & 13.25 & 23.03 & 35.21 & 46.61 & 54.17 \\
\hline $\mathrm{T}_{6}$ & $155: 55: 55 \mathrm{~kg} / \mathrm{ha}$ NPK & 26.26 & 40.67 & 57.27 & 79.67 & 107.27 & 12.37 & 22.49 & 34.67 & 46.13 & 53.71 \\
\hline $\mathrm{T}_{7}$ & 175:55:45 kg/ha NPK & 35.76 & 50.10 & 66.73 & 89.10 & 116.70 & 13.37 & 23.49 & 35.70 & 47.07 & 54.32 \\
\hline $\mathrm{T}_{8}$ & 175:70:35 kg/ha NPK & 27.6 & 42.00 & 58.60 & 81.00 & 108.60 & 12.64 & 22.76 & 34.94 & 46.34 & 54.15 \\
\hline $\mathrm{T}_{9}$ & 175:70:55 kg/ha NPK & 31.03 & 45.37 & 61.97 & 84.37 & 111.97 & 13.01 & 23.13 & 35.31 & 46.71 & 54.21 \\
\hline F Test & & $\mathrm{S}$ & $\mathrm{S}$ & $\mathrm{S}$ & $\mathrm{S}$ & $\mathrm{S}$ & & $\mathrm{S}$ & $\mathrm{S}$ & $\mathrm{S}$ & $\mathrm{S}$ \\
\hline C.D.at $5 \%$ & & 2.12 & 2.21 & 2.22 & 2.36 & 2.29 & & 1.77 & 1.79 & 1.69 & 1.70 \\
\hline
\end{tabular}

DAT-Days after transplanting 
Int.J.Curr.Microbiol.App.Sci (2017) 6(3): 1085-1091

Table.2 Yield and quality parameters capsicum influenced by different doses of NPK in shade net condition

\begin{tabular}{|c|c|c|c|c|c|c|c|c|c|}
\hline \multirow[t]{2}{*}{ Treatment } & \multirow[t]{2}{*}{ Treatment combination } & \multicolumn{4}{|c|}{ Yield Parameters } & \multirow[b]{2}{*}{$\begin{array}{c}\text { Fruit } \\
\text { Yield/ } \\
\text { plant } \\
(\mathbf{k g}) \\
\end{array}$} & \multirow[b]{2}{*}{$\begin{array}{l}\text { Fruit } \\
\text { Yield/ } \\
\text { green } \\
\text { house }\end{array}$} & \multicolumn{2}{|c|}{ Quality Parameters } \\
\hline & & $\begin{array}{c}\text { No. of } \\
\text { fruit/pla } \\
\text { nt }\end{array}$ & $\begin{array}{c}\text { Fruit } \\
\text { length } \\
(\mathrm{cm})\end{array}$ & $\begin{array}{c}\text { Fruit } \\
\text { diameter } \\
(\mathrm{cm})\end{array}$ & $\begin{array}{c}\text { Weight } \\
\text { Fruits (g) }\end{array}$ & & & $\begin{array}{c}\text { Shelf life } \\
\text { (days) }\end{array}$ & $\begin{array}{c}\text { TSS } \\
\left(\text { Brix }^{0}\right)\end{array}$ \\
\hline $\mathrm{T}_{1}$ & 135:40:35kg/ha NPK & 4.90 & 6.47 & 4.64 & 173.00 & 0.84 & 136.62 & 5.40 & 5.34 \\
\hline $\mathrm{T}_{2}$ & 135:40:55 kg/ha NPK & 7.20 & 8.31 & 6.85 & 187.99 & 1.35 & 218.16 & 6.80 & 5.62 \\
\hline $\mathrm{T}_{3}$ & 135:55:45 kg/ha NPK & 6.80 & 7.82 & 5.98 & 196.00 & 1.33 & 214.92 & 6.50 & 5.55 \\
\hline $\mathrm{T}_{4}$ & 155:40:35 kg/ha NPK & 5.50 & 6.86 & 5.31 & 203.00 & 1.12 & 181.44 & 5.70 & 5.48 \\
\hline $\mathrm{T}_{5}$ & $155: 55: 45 \mathrm{~kg} / \mathrm{ha} \mathrm{NPK}$ & 8.70 & 9.12 & 7.95 & 229.00 & 1.99 & 321.84 & 7.43 & 5.68 \\
\hline $\mathrm{T}_{6}$ & 155:55:55 kg/ha NPK & 7.6 & 9.61 & 8.01 & 230.99 & 1.75 & 283.50 & 7.60 & 5.82 \\
\hline $\mathrm{T}_{7}$ & 175:55:45 kg/ha NPK & 7.89 & 8.03 & 6.1 & 207.99 & 1.64 & 265.14 & 6.70 & 5.60 \\
\hline $\mathrm{T}_{8}$ & 175:70:35 kg/ha NPK & 6.10 & 7.53 & 5.88 & 216.99 & 1.32 & 214.38 & 6.20 & 5.52 \\
\hline $\mathrm{T}_{9}$ & 175:70:55 kg/ha NPK & 8.20 & 8.5 & 7.81 & 224.00 & 1.83 & 297.00 & 7.10 & 5.63 \\
\hline F Test & & $\mathbf{S}$ & $\mathbf{S}$ & $\mathbf{S}$ & $\mathbf{S}$ & $\mathbf{S}$ & $\mathbf{S}$ & $\mathbf{S}$ & $\mathbf{S}$ \\
\hline $\mathrm{CD}$ at $5 \%$ & & 0.02 & 0.46 & 0.35 & 0.38 & 0.015 & 1.16 & 0.55 & 0.17 \\
\hline
\end{tabular}


The maximum fruit length $(\mathrm{cm})$ was recorded in T6: $155: 55: 55 \mathrm{~kg} / \mathrm{ha}$ with $(9.61 \mathrm{~cm})$, followed by T5: 155:55:45 $\mathrm{kg} / \mathrm{ha}$ with $(9.12 \mathrm{~cm})$ and the minimum was recorded in T1: (control) with 135:40:35 $\mathrm{kg} / \mathrm{ha}$ with $(6.47 \mathrm{~cm})$. Sufficient quantity of the fertilizers i.e. nitrogen, phosphorus and specially potassium, fulfilled the need of plants to attain more vigor, flowering and fruit development thereby resulting in good quality and large size (length) of fruits. Result shows that the maximum diameter of fruits, which reveals that different levels of Nitrogen, Phosphorus, particularly Potassium plays dynamic role and significantly influence the production and development of good quality and large size (length and radial) of fruits.

The maximum fruit diameter $(\mathrm{cm}$.$) was$ recorded in T6: 155:55:55 $\mathrm{kg} / \mathrm{ha}$ with $(8.01 \mathrm{~cm})$ followed by T5: $155: 55: 45 \mathrm{~kg} / \mathrm{ha}$ with $(7.95 \mathrm{~cm})$ and the minimum was recorded in T1: (control) with 135:40:35 kg/ha with $(4.64 \mathrm{~cm})$. Simultaneously Potassium with Nitrogen and Phosphorus plays vigorous role to produce good quality as well as huge size of fruits which will attain the higher production of fruits. The maximum fruit weight (gm.) was recorded in was recorded in T6: $155: 55: 55 \mathrm{~kg} / \mathrm{ha}$ with $(230.99 \mathrm{gm})$, followed by $\mathrm{T} 5$ : $155: 55: 45 \mathrm{~kg} / \mathrm{ha}$ with $(229.00 \mathrm{gm})$ and the minimum was recorded in T1: (control) with $(135: 40: 35 \mathrm{~kg} / \mathrm{ha}$ with (173.00gm).

The maximum fruit yield per plant $(\mathrm{kg})$ was recorded in T5: 155:55:45 $\mathrm{kg} / \mathrm{ha}$ with $(1.99 \mathrm{~kg})$ followed by $\mathrm{T} 9: 175: 70: 55 \mathrm{~kg} / \mathrm{ha}$ with $(1.83 \mathrm{~kg})$ and the minimum was recorded in T1: (control) with $(135: 40: 35 \mathrm{~kg} / \mathrm{ha}$ with $(0.84 \mathrm{~kg})$ (Table 2$)$. These findings are in conformity with the results reported by Balliu et al., (2007); Aminifard et al., (2012) and Yasuor, (2013). The maximum fruit yield $(\mathrm{kg})$ / green house was recorded inT5: 155:55:45 $\mathrm{kg} / \mathrm{ha}$ with $(321.84 \mathrm{~kg})$ followed by $\mathrm{T} 9$ :
$175: 70: 55 \mathrm{~kg} / \mathrm{ha}$ with $(297.00 \mathrm{~kg})$ and the minimum $(136.62 \mathrm{~kg})$ was recorded in $\mathrm{T} 1$ : (control) with $(135: 40: 35 \mathrm{~kg} / \mathrm{ha}$. The maximum total soluble solids ( ${ }^{0}$ Brix) was recorded in T6: 155:55:55 $\mathrm{kg} / \mathrm{ha}$ with (5.820B), followed by T5: 155:55:45 $\mathrm{kg} / \mathrm{ha}$ with $(5.680 \mathrm{~B})$ and the minimum was recorded in T1: (control) with $(135: 40: 35 \mathrm{~kg} / \mathrm{ha}$ with (5.340B).

An increasing trend in total soluble solids with the increase in levels of potassium was observed and the maximum total soluble solids were recorded with the combination of highest levels of potassium applied. These results are supported by the findings reported by Contreras et al., (2006); Balliu et al., (2007) and Aminifard et al., (2012).

The maximum shelf life (days) was recorded in T6: $155: 55: 55 \mathrm{~kg} / \mathrm{ha}$ with (7.60 days), followed by $\mathrm{T} 5: 155: 55: 45 \mathrm{~kg} / \mathrm{ha}$ with $(7.43$ days) and the minimum was recorded in $\mathrm{T} 1$ : (control) with $(135: 40: 35 \mathrm{~kg} / \mathrm{ha}$ with $(5.40$ days). These findings are in conformity with the results reported by Contreras et al., (2006); Balliu et al., (2007) and Aminifard et al., (2012). The highest gross returns (11586240Rs/ha), net returns (9724914Rs/ha) and cost benefit ratio (5.22) was recorded in T5: 155:55:45 NPK/ha followed by T6 with gross returns (10206000Rs/ha), net returns (8344412Rs/ha) and cost benefit ratio (4.48), whereas the minimum gross returns (4918320Rs/ha), net returns (3060950Rs/ha) and cost benefit ratio (1.64) was observed In T1 (control).

Above results clearly shows that application of NPK@155:55:45 kg/ha proved to be the most suitable combination of nitrogen, phosphorus and potassium in relation to growth yield and quality and economic returns for cultivation of capsicum under shade condition under agro climatic conditions of Allahabad. 


\section{References}

Abdelaziz, M.E., Ahmed, A.H.H., Bekhid, R.S., and Pokluda, R. 2008. Response of growth patterns in sweet pepper to different NPK levels. Acta Universitatis Agriculturaeet Silviculturae Mendelianae Brunensis, 56(1): 241-244.

Aminifard, M.H., Aroiee, H., Ameri, A., and Fatemi, H. 2012. Effect of plant density and nitrogen fertilizer on growth, yield and fruit quality of sweet pepper $(C$. annum L.). African J. Agri. Res., 7(6): $859-866$.

Balliu, A., Bani, A., and Sulce, S. 2007. Nitrogen effects on the relative growth rate and its components of pepper (C.annuum) and eggplant (Solanummelongena) seedlings. Acta Universitatis Agriculturaeet Silviculture Mendelianae Brunensis, 56(1): 241244.

Contreras, J.I., Segura, M.L., Galindo, P., and Catala, J.J. 2006. Response of greenhouse pepper crop to fertilizer level and different qualities of irrigation water. Acta Horticulture, 700: 203-206.

Horticultural Statistics at a Glance. 2015. Horticulture Statistics Division, Department of Agriculture, Cooperation and Farmers Welfare, Ministry of Agriculture and Farmers Welfare, Government of India.
Khan, A., Shah, S.N.M., Rab, A., Sajid, M., Ali, K., Ahmed, A. and Faisal, S. 2014. Influence of Nitrogen and potassium levels on growth and yield of chilies. Int. J. Farming and Allied sci., Vol., 3(3): 260-264.

Lebauer, S.D., and Treseder, K.K. 2008. Nitrogen limitation of net primary productivity in terrestrial ecosystems is globally distributed. Ecol. Soc. America, 89(2): 371-379.

Lester, G.E., Jifon, J.L., and Makus, D.J. 2006. Supplemental foliar potassium applications with or without a surfactant can enhance netted muskmelon quality. Hortsci., 41(3): 741-744.

Naz, S., Anjum, M.A., and Ahmad, I. 2006. Growth of chilli (C. annuum L.) F1 hybrid sky line-2 in response to different ages of transplants. J. Res. (Sci)., 17: 91-95.

Tumbare, A.D., and D.R. Niikam. 2004. Effect of planting and fertigation on growth and yield of greenchili $(C$. annuum). Indian J. Agri. Sci., 74: 242245.

Yasuor, H., Ben-Gal, A., Yermiyahu, U., Beit-Yannai, E. and Cohen, S. 2013. Nitrogen management of greenhouse pepper production: agronomic, nutritional, and environmental implications. Hortsci., 48(10): 1241-1249.

\section{How to cite this article:}

Ashish Kumar Dubey, Devi Singh, Pranjal Singh Rajput, Yogesh Kumar, Ajay Kumar Verma and Sandip Kumar Chandraker. 2017. Effect of NPK on Plant Growth, Yield and Quality of Capsicum (Capsicum annum L.) c.v. Swarna Under Shade Net Condition. Int.J.Curr.Microbiol.App.Sci. 6(3): 1085-1091. doi: https://doi.org/10.20546/ijcmas.2017.603.125 